\title{
Electrochemical Investigations of $\mathrm{Li}_{2} \mathrm{Fe}_{0.8-\mathrm{x}} \mathrm{Mn}_{0.2} \mathrm{M}_{\mathrm{x}} \mathrm{SiO}_{4}\left(\mathrm{M}=\mathrm{Mg}^{2+}, \mathrm{Zn}^{2+}\right)$ Cathodes for Lithium Ion Batteries
}

\author{
Shu-Dan Li, Yun Zhao, Chen-Yi Wang and Kun Gao* \\ School of Chemistry and Materials Science, Shanxi Normal University, 041004 Linfen, China
}

\begin{abstract}
The $\mathrm{Mn}^{2+}$ and $\mathrm{Mg}^{2+}$ (or $\mathrm{Zn}^{2+}$ ) co-doped $\mathrm{Li}_{2} \mathrm{Fe}_{0.8-\mathrm{x}} \mathrm{Mn}_{0.2} \mathrm{M}_{\mathrm{x}} \mathrm{SiO}_{4}(\mathrm{x}=0.05$ and 0.1 ) are synthesized by a solid-state reaction route. Compared with the single doped $\mathrm{Li}_{2} \mathrm{Fe}_{0.8} \mathrm{Mn}_{0.2} \mathrm{SiO}_{4}$, the co-doped samples show improved cycling performance. The capacity retention can stay above $50 \%$ after 50 cycles, which is significantly higher than $30.4 \%$ for $\mathrm{Li}_{2} \mathrm{Fe}_{0.8} \mathrm{Mn}_{0.2} \mathrm{SiO}_{4}$. This phenomenon could be attributed to the increased structural stability caused by the incorporation of the electrochemically inactive $\mathrm{M}^{2+}$ ions. However, except for $\mathrm{Li}_{2} \mathrm{Fe}_{0.75} \mathrm{Mn}_{0.2} \mathrm{Mg}_{0.05} \mathrm{SiO}_{4}$, the other samples show decreased capacities, especially in the case of the $\mathrm{Mn} / \mathrm{Zn}$ co-doping. Further tests indicate that the promotion of $\mathrm{Li}^{+}$diffusivity may be a key reason for the improved rate and cycling performances. By contrast, the incorporation of $\mathrm{Zn}^{2+}$ impaired the cell performances such as increased internal polarization, hindered charge transfer, decreased $\mathrm{Li}^{+}$diffusivity. In this work, the $\mathrm{Mg}^{2+}$ with smaller radius seems to be a better choice as the co-doping element at Fe sites than $\mathrm{Zn}^{2+}$.
\end{abstract}

Keywords: chemically modified electrode, lithium battery, applied electrochemistry, composite and nanocomposite materials

\section{Introduction}

Compared with the other cathodes from the silicate family, $\mathrm{Li}_{2} \mathrm{FeSiO}_{4}$ has its own characteristics, such as: structural rearrangement, stable interface film, thermal regeneration. However, low electronic conductivity and slow lithium-ion diffusion are the biggest obstacles for the commercial application of $\mathrm{Li}_{2} \mathrm{FeSiO}_{4}$. To date, numerous approaches have been investigated to circumvent these main issues by improving the intrinsic and extrinsic properties of bulk $\mathrm{Li}_{2} \mathrm{FeSiO}_{4}$, by e.g., cation doping, carbon coating and optimized preparation technology, etc. Some nano- $\mathrm{Li}_{2} \mathrm{FeSiO}_{4} / \mathrm{C}$ composites with novel shapes, such as $\mathrm{Li}_{2} \mathrm{FeSiO}_{4} / \mathrm{C} / \mathrm{CNS},{ }^{1}$ hierarchical shuttle-like $\mathrm{Li}_{2} \mathrm{FeSiO}_{4} / \mathrm{C},{ }^{2}$ rod like $\mathrm{Li}_{2} \mathrm{FeSiO}_{4}{ }^{3}$ and nano-spherical $\mathrm{Li}_{2} \mathrm{FeSiO}_{4} / \mathrm{C}$, ${ }^{4}$ can approach or even exceed the theoretical capacity of $166 \mathrm{mAh} \mathrm{g}^{-1}$. Especially, the $\mathrm{Li}_{2} \mathrm{FeSiO}_{4} / \mathrm{C} / \mathrm{MWCNTs}$ (MWCNTs: multi walled carbon nanotubes) composites reported by Peng et al. ${ }^{5}$ had a high discharge capacity of $206.8 \mathrm{~mA} \mathrm{~h} \mathrm{~g}^{-1}$ in the second cycle at $0.1 \mathrm{C}$, even at $20 \mathrm{C}$, the electrode could maintain $82 \mathrm{mAh} \mathrm{g}^{-1}$ after 500 cycles. Moreover, the porous $\mathrm{Li}_{2} \mathrm{FeSiO}_{4} / \mathrm{C}$ nano-composites prepared by a simple $\mathrm{P} 123\left(\mathrm{EO}_{20} \mathrm{PO}_{70} \mathrm{EO}_{20}\right)$ assisted sol-gel method, also delivered a first discharge capacity

*e-mail: gaokun0451@163.com of $230 \mathrm{mAh} \mathrm{g}^{-1}$ at $0.1 \mathrm{C}$ corresponding to $1.39 \mathrm{~mol} \mathrm{Li}^{+}$ inserted per molecular formula. ${ }^{6}$ These works indicate that $\mathrm{Li}_{2} \mathrm{FeSiO}_{4}$ has a lot of potential as a promising cathode material for Li-ion battery.

In the past few years, cation doping was considered as one of the most effective methods to improve electronic conductivity and ion mobility. Various doping elements have been tried to improve the performance of $\mathrm{Li}_{2} \mathrm{FeSiO}_{4}$ materials. For example, Zhang et al. ${ }^{7}$ studied the impact of different doping elements including $\mathrm{Mg}^{2+}, \mathrm{Zn}^{2+} / \mathrm{Cu}^{2+} / \mathrm{Ni}^{2+}$, $\mathrm{Cr}^{3+}, 9$ on the electrochemical performance of $\mathrm{Li}_{2} \mathrm{FeSiO}_{4}$, and some improved results were observed. Among the related reports, $\mathrm{Mn}^{2+}$ doping is of special concern, because $\mathrm{Mn}^{2+}$ ion can solve into the crystal structure of $\mathrm{Li}_{2} \mathrm{FeSiO}_{4}$, and make up for the intrinsic disadvantage of low theoretical capacity $\left(166 \mathrm{mAh} \mathrm{g}^{-1}\right)$. For example, Shao et al. ${ }^{10}$ prepared carbon-coated nanostructured $\mathrm{Li}_{2} \mathrm{Fe}_{0.5} \mathrm{Mn}_{0.5} \mathrm{SiO}_{4}$ via a combination of spray pyrolysis and wet ball milling method, which displayed a discharge capacity as high as $149 \mathrm{mAh} \mathrm{g}^{-1}$. Different from the above optimum Fe/Mn ratio, Guo et al. ${ }^{11}$ pointed out that $\mathrm{Li}_{2} \mathrm{Fe}_{0.9} \mathrm{Mn}_{0.1} \mathrm{SiO}_{4} / \mathrm{C}$ synthesized by mechanical activation-solid-state reaction had a distinguished discharge capacity of $158.1 \mathrm{mAh} \mathrm{g}^{-1}$ in the first cycle. ${ }^{10}$ Deng et al. ${ }^{12}$ also reported that the $\mathrm{Li}_{2} \mathrm{Fe}_{0.5} \mathrm{Mn}_{0.5} \mathrm{SiO}_{4}$ prepared via citric acid assisted sol-gel method showed an initial discharge capacity above 
$170 \mathrm{mAh} \mathrm{g}^{-1}$. Especially, $\mathrm{Li}_{2} \mathrm{Fe}_{0.75} \mathrm{Mn}_{0.25} \mathrm{SiO}_{4} / \mathrm{C}$ reported by Wang and co-workers ${ }^{13}$ using a modified sol-gel methods, inserted more than $1.0 \mathrm{~mol} \mathrm{Li}^{+}$per molecular formula, and showed an initial discharge capacity of $201 \mathrm{mAh} \mathrm{g}^{-1}$. However, all the Mn-doped samples presented worse cycling performance than pristine materials. About this, Bini et al. ${ }^{14}$ pointed out that a significant cation disorder could top up to $80 \%$, based on the $\mathrm{Li} / \mathrm{Fe}(\mathrm{Mn})$ anti-site defect, which should seriously influence the structural stability of $\mathrm{Li}_{2} \mathrm{Fe}_{1-\mathrm{x}} \mathrm{Mn}_{\mathrm{x}} \mathrm{SiO}_{4} / \mathrm{C}$ composites. Moreover, Chen et al. ${ }^{15}$ also found out that the amorphization and structural rearrangements of $\mathrm{Li}_{2} \mathrm{Fe}_{1-\mathrm{x}} \mathrm{Mn}_{\mathrm{x}} \mathrm{SiO}_{4}$ during the initial cycle and the redox processes of $\mathrm{Mn}$ species could be only involved in the first few cycles. Therefore, the structural stability and the efficiency of Mn species are the main problem facing the current ferromanganese lithium silicate materials.

Recently, the introduction of a second dopant has been proposed and widely studied in order to improve the electrochemical response of cathode material. Hu et al. ${ }^{16}$ compared the properties of single doped $\mathrm{LiMn}_{0.9} \mathrm{Fe}_{0.1} \mathrm{PO}_{4}$ and co-doped $\mathrm{LiMn}_{0.9} \mathrm{Fe}_{0.05} \mathrm{Mg}_{0.05} \mathrm{PO}_{4}$, and found that the $\mathrm{LiMn}_{0.9} \mathrm{Fe}_{0.05} \mathrm{Mg}_{0.05} \mathrm{PO}_{4}$ sample has much higher reversible capacity and rate capability as compared to $\mathrm{LiMn}_{0.9} \mathrm{Fe}_{0.1} \mathrm{PO}_{4}$. Cui et al. ${ }^{16}$ synthesized zinc- and $\mathrm{PO}_{4}$-doped $\mathrm{LiMn}_{2} \mathrm{O}_{4}$ via traditional solid state reaction. The discharge capacity and cycling performance of the co-doped $\mathrm{LiZn}_{0.05} \mathrm{Mn}_{1.95} \mathrm{O}_{3.96}\left(\mathrm{PO}_{4}\right)_{0.025}$ were found to be superior to single doped $\mathrm{LiZn}_{0.05} \mathrm{Mn}_{1.95} \mathrm{O}_{3.99}$.

With the expectation to improve the cycling capability of $\mathrm{Li}_{2} \mathrm{Fe}_{1-\mathrm{x}} \mathrm{Mn}_{\mathrm{x}} \mathrm{SiO}_{4}$ system, we choose common divalent cations $\left(\mathrm{Mg}^{2+}\right.$ and $\left.\mathrm{Zn}^{2+}\right)$ combined with $\mathrm{Mn}^{2+}$ as the co-doping elements at $\mathrm{Fe}$ sites and prepared $\mathrm{Li}_{2} \mathrm{Fe}_{0.8 \mathrm{x}} \mathrm{Mn}_{0.2} \mathrm{M}_{\mathrm{x}} \mathrm{SiO}_{4}$ $(\mathrm{M}=\mathrm{Mg}$ or $\mathrm{Zn}, \mathrm{x}=0.05,0.1)$ cathodes by a solid state reaction. Their electrochemical properties were investigated and the possible synergistic mechanisms were discussed.

\section{Experimental}

The used metal salts: $\mathrm{LiCH}_{3} \mathrm{COO} .2 \mathrm{H}_{2} \mathrm{O}, \mathrm{FeC}_{2} \mathrm{O}_{4} \cdot 2 \mathrm{H}_{2} \mathrm{O}$, $\mathrm{Mn}\left(\mathrm{CH}_{3} \mathrm{COO}\right)_{2} \cdot 4 \mathrm{H}_{2} \mathrm{O}, \mathrm{ZnO}$ and $\mathrm{Mg}\left(\mathrm{CH}_{3} \mathrm{COO}\right)_{2} \cdot 4 \mathrm{H}_{2} \mathrm{O}$, were purchased from Tianjin Guangfu Fine Chemical Research Institute, and nano- $\mathrm{SiO}_{2}$ was provided from Henan Huanyu Power Source Co., Ltd. To prepare cathode materials, the stoichiometric amounts of $\mathrm{SiO}_{2}$ and metal salts were first mixed together. To avoid the excessive impurities in the final products, only 5 wt. $\%$ mass of glucose $\left(\mathrm{C}_{6} \mathrm{H}_{12} \mathrm{O}_{6} \cdot \mathrm{H}_{2} \mathrm{O}\right)$ as carbon source was introduced to the above mixture, and the mixture were ground to fine powder together with an agate mortar and pestle. The resulting intimate mixtures were first dehydrated at $200{ }^{\circ} \mathrm{C}$ for $1 \mathrm{~h}$, and then calcined at $700{ }^{\circ} \mathrm{C}$ for $10 \mathrm{~h}$ in a vacuum tube furnace keeping $-0.1 \mathrm{MPa} v s$. normal atmosphere. According to the ratio of metal salts in the initial precursor, the obtained final products with about $1.6 \mathrm{wt} . \%$ carbon (determined by high frequency infrared carbon-sulfur determination, CS 600, Germany Eltar), were named as $\mathrm{Li}_{2} \mathrm{Fe}_{0.8-\mathrm{x}} \mathrm{Mn}_{0.2} \mathrm{M}_{0.05} \mathrm{SiO}_{4}$ or $\mathrm{Li}_{2} \mathrm{Fe}_{0.8-\mathrm{x}} \mathrm{Mn}_{0.2} \mathrm{M}_{0.1} \mathrm{SiO}_{4}(\mathrm{M}=\mathrm{Mg}$ or $\mathrm{Zn})$.

The crystal structures were analyzed by powder X-ray diffraction (Ultima IV, Rigaku) employing $\mathrm{Cu} \mathrm{K}_{\mathrm{al}}$ radiation $(\lambda=0.154056 \mathrm{~nm})$ in the two-theta range of $10-80^{\circ}$. The morphologies and chemical distributions were observed using a field-emission scanning electron microscope (FESEM, JSM-7500F, Japan JEOL) equipped with an energy dispersive X-ray analyzer (EDX, Oxford Inca PentaFET $\times 3$ ).

The mixture of $\mathrm{Li}_{2} \mathrm{Fe}_{0.8-\mathrm{x}} \mathrm{Mn}_{0.2} \mathrm{M}_{\mathrm{x}} \mathrm{SiO}_{4}$ powder, acetylene black and polyvinylidene fluoride with a weight ratio of 80:10:10 was used as the cathode. The dry strip cathodes were cut into the disks (16 $\mathrm{mm}$ in diameter) containing 6-8 $\mathrm{mg}$ active materials. Then, the $\mathrm{Li}_{2} \mathrm{Fe}_{0.8-\mathrm{x}} \mathrm{Mn}_{0.2} \mathrm{M}_{\mathrm{x}} \mathrm{SiO}_{4} / \mathrm{Li}$ coin cells were fabricated in an Ar-filled glove box. The cycling and rate performances were characterized on a $5 \mathrm{~V}$ per $2 \mathrm{~mA}$ battery testing system (Land 2005A, Wuhan Jinnuo Electronics Co., Ltd.) with cut-off voltage of 1.5-4.5 Vvs. $\mathrm{Li}^{+} / \mathrm{Li}$ at a constant current from 0.06 to 2 C. The electrochemical impedance spectra (EIS) of the cycled cells were obtained using an electrochemical workstation (CHI 604D, Shanghai CH Instruments, Inc.) in a range of $0.1-100 \mathrm{kHz}$ at the amplitude of $5 \mathrm{mV}$. The cyclic voltammetry (CV) was also tested with CHI 604D at a scanning rate of $1.0 \mathrm{mV} \mathrm{s}^{-1}$ at room temperature. Capacity intermittent titration technique (CITT) proposed by Tang et al. ${ }^{18}$ was used to investigate the Li-ion diffusion coefficient $\left(\mathrm{D}_{\mathrm{Li}+}\right)$. The cell was first galvanostaticallycharged $\left(5 \mathrm{~mA} \mathrm{~g}^{-1}\right)$ to a certain cutoff voltage, then potentiostatically-charged at this cutoff voltage until the current tends to zero. Here, the set current is $0.05 \mathrm{~mA} \mathrm{~g}^{-1}$. The whole charge voltage ranges (1.5-4.5 V) were divided into many small voltage regions and separated from one another by $0.1 \mathrm{~V}$. When the charging was completed, the tested cell was discharged with $10 \mathrm{~mA} \mathrm{~g}^{-1}$ current to $2.0 \mathrm{~V}$. The above procedures were continuously repeated for five cycles.

\section{Results and Discussion}

Figure 1 compares the $\mathrm{X}$-ray diffraction (XRD) patterns of the synthesized $\mathrm{Li}_{2} \mathrm{Fe}_{0.8-\mathrm{x}} \mathrm{Mn}_{0.2} \mathrm{M}_{\mathrm{x}} \mathrm{SiO}_{4}$ samples. The $\mathrm{Li}_{2} \mathrm{Fe}_{3} \mathrm{O}_{4}$ impurity can be easily detected, small $\mathrm{Li}_{2} \mathrm{SiO}_{3}$ also emerged in the $\mathrm{Mn} / \mathrm{Mg}$ co-doped samples. The remaining diffraction peaks are very similar to each other, 
indicating that small amounts of co-doping elements have not changed $\mathrm{Li}_{2} \mathrm{FeSiO}_{4}$ architecture. However, the broad peaks indicate that in neither case the crystallinity is good. The quality of XRD patterns does not allow a good Rietveld refinement, but the matching results of XRD patterns, especially in low angle region, suggest that the obtained samples should be a mixed phases of $\mathrm{P} 2_{1} / \mathrm{n}$ and Pmn $2{ }_{1}$ co-existance. ${ }^{19}$ Furthermore, the co-doping of $\mathrm{Mg}^{2+}$ or $\mathrm{Zn}^{2+}$ caused some observable variations in the diffraction peak positions. For example, the strongest diffraction peak around $33^{\circ}$ gradually shifted toward higher $2 \theta$ values with the increase of $\mathrm{Mg}$ content from 0 to 0.1 , which could be easily seen from the enlarged patterns located at the right side of Figure 1. Recently, Dimesso et al. ${ }^{20}$ reported the influence of different $\mathrm{Mg}$-ion additions on the structure of the olivine-structured $\mathrm{LiCo}_{1-x} \mathrm{Mg}_{x} \mathrm{PO}_{4}$. Their results showed a shift in the positions of the (311) and (121) reflections towards higher diffraction angles. By contrast, due to the similar radius of $\mathrm{Zn}^{2+}(0.74 \AA)$ and $\mathrm{Fe}^{2+}(0.76 \AA)$, the $\mathrm{Mn} /$ $\mathrm{Zn}$ co-doping did not cause changing in the position of the reflection at $33^{\circ} / 2 \theta$, and a shoulder peak always well evident. The XRD results suggest that $\mathrm{Mg}^{2+}$ and $\mathrm{Zn}^{2+}$ have been successfully introduced into $\mathrm{Li}_{2} \mathrm{FeSiO}_{4}$ matrix structure. ${ }^{10,21-23}$ Moreover, the XRD patterns do not show any peak related to crystal carbon, which indicates the introduced carbon should be in amorphous form in the final samples.

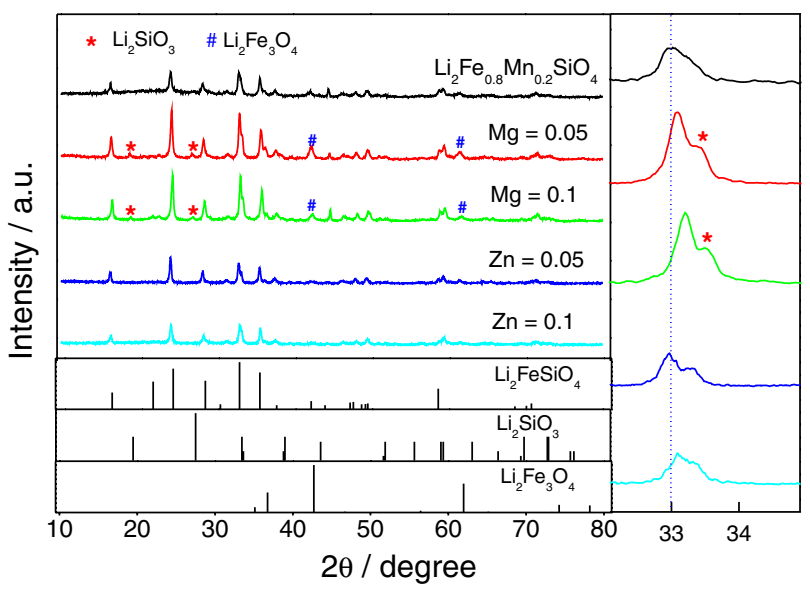

Figure 1. XRD patterns of $\mathrm{Li}_{2} \mathrm{Fe}_{0.8-\mathrm{x}} \mathrm{Mn}_{0.2} \mathrm{M}_{\mathrm{x}} \mathrm{SiO}_{4}(\mathrm{M}=\mathrm{Mg}$ and $\mathrm{Zn}, \mathrm{x}=0$, 0.05 and 0.1 ).

To clarify the surfacial characteristics of $\mathrm{Li}_{2} \mathrm{Fe}_{0.8-\mathrm{x}} \mathrm{Mn}_{0.2} \mathrm{M}_{\mathrm{x}} \mathrm{SiO}_{4}$ samples, SEM (scanning electron microscopy) observations were carried out in combination with EDX tests. As shown in Figure 2, there were no significant morphological differences between these SEM images. All samples exhibited agglomerated particles mainly arising from the employed solid-phase method.
However, based on the local view, the $\mathrm{Mn} / \mathrm{Zn}$ co-doping seems to produce more serious agglomerates and less uniform particle size. The further EDX (energy dispersive $\mathrm{X}$-ray) spot data in Table 1 show that the atomic ratio of $\mathrm{Fe} / \mathrm{Mn} / \mathrm{M} / \mathrm{Si} / \mathrm{O}$ in samples was very close to the designed ratio of the $\mathrm{Li}_{2} \mathrm{Fe}_{0.8-x} \mathrm{Mn}_{0.2} \mathrm{M}_{\mathrm{x}} \mathrm{SiO}_{4}$ formula. It demonstrates that the co-doped elements incorporate very well with $\mathrm{Li}_{2} \mathrm{Fe}_{0.8-\mathrm{x}} \mathrm{Mn}_{0.2} \mathrm{M}_{\mathrm{x}} \mathrm{SiO}_{4}$ host materials.

Although $\mathrm{Li}_{2} \mathrm{FeSiO}_{4}$ capacity could be greatly improved by $\mathrm{Mn}^{2+}$ doping, $\mathrm{Li}_{2} \mathrm{Fe}_{0.8} \mathrm{Mn}_{0.2} \mathrm{SiO}_{4}$ has been demonstrated experimentally with the $30-40 \%$ capacity loss after 50 charge-discharge cycles in many reports. ${ }^{10,12,24} \mathrm{~A}$ similar observation can be seen in our experiments. As shown in Figure $3 b$, the $\mathrm{Li}_{2} \mathrm{Fe}_{0.8} \mathrm{Mn}_{0.2} \mathrm{SiO}_{4} / \mathrm{Li}$ cell exhibited a serious capacity loss and only maintained about $30.4 \%$ of discharge capacity at $50^{\text {th }}$ cycle $\left(38.6 \mathrm{mAh} \mathrm{g}^{-1}\right)$, as compared to that at $1^{\text {st }}$ cycle $\left(127 \mathrm{mAh} \mathrm{g}^{-1}\right)$. Moreover, it is necessary to point out that the present $\mathrm{Li}_{2} \mathrm{Fe}_{0.8} \mathrm{Mn}_{0.2} \mathrm{SiO}_{4}$ performance is lower than that in our previous report. ${ }^{25}$ This is because that smaller carbon was introduced in the present series experiments in order to avoid more impurities resulting from excessive carbon, and highlight the effect of codoping.

Based on the charge-discharge data in Figure 3, we can summarize some key things as follow: $(i)$ the initial charge curves of all samples are obviously higher than those in the subsequent cycles, which means that the single-doping of $\mathrm{Mn}^{2+}$ or the further co-doping of $\mathrm{Mg}^{2+}$ or $\mathrm{Zn}^{2+}$ do not change the inherent characteristic of structural rearrangement of $\mathrm{Li}_{2} \mathrm{FeSiO}_{4}$ material; ${ }^{26,27}$ (ii) the initial dQ-dV curves in Figure $3 \mathrm{a}$ exhibit two clear voltage plateaus at about 3.5 and 4. $4 \mathrm{~V}$. After $\mathrm{Mg}^{2+}$ or $\mathrm{Zn}^{2+}$ co-doping, the area of oxidation peak located at about $3.5 \mathrm{~V}$ increases. At the same time, a shift of reduction peak located at about $2.5 \mathrm{~V}$ towards the right means less internal polarization. Novikova et al. ${ }^{28}$ also observed similar phenomenon that the slope of the voltage plateau for the co-doped samples is lower than that of single-doped sample, and they attribute it to the improved ionic conductivity; (iii) the initial discharge capacities of the co-doped samples are lower than that of $127 \mathrm{mAh} \mathrm{g}^{-1}$ for the single-doped sample. For example, in the case of the $\mathrm{Mn} / \mathrm{Mg}$ co-doped samples, when $\mathrm{x}$ is 0.05 and 0.1 , the initial discharge capacities are 118 and $108.5 \mathrm{mAh} \mathrm{g}^{-1}$, respectively. As for the $\mathrm{Mn} / \mathrm{Zn}$ co-doped samples, lower discharge capacities of 96.8 and $79.6 \mathrm{mAh} \mathrm{g}^{-1}$ are observed. This result can be interpreted as being due to the fact that the doped $\mathrm{Mg}^{2+}$ or $\mathrm{Zn}^{2+}$ in the crystal lattice cannot be oxidized to $\mathrm{M}^{3+}$ or $\mathrm{M}^{4+}$, they usually stay electrochemically inactive. ${ }^{29}$ The fact that the more $\mathrm{M}^{2+}$ co-doping causes the lower discharge capacities is in agreement with the above inference. (iv) Cycling performances have been greatly improved by co-doping. For 

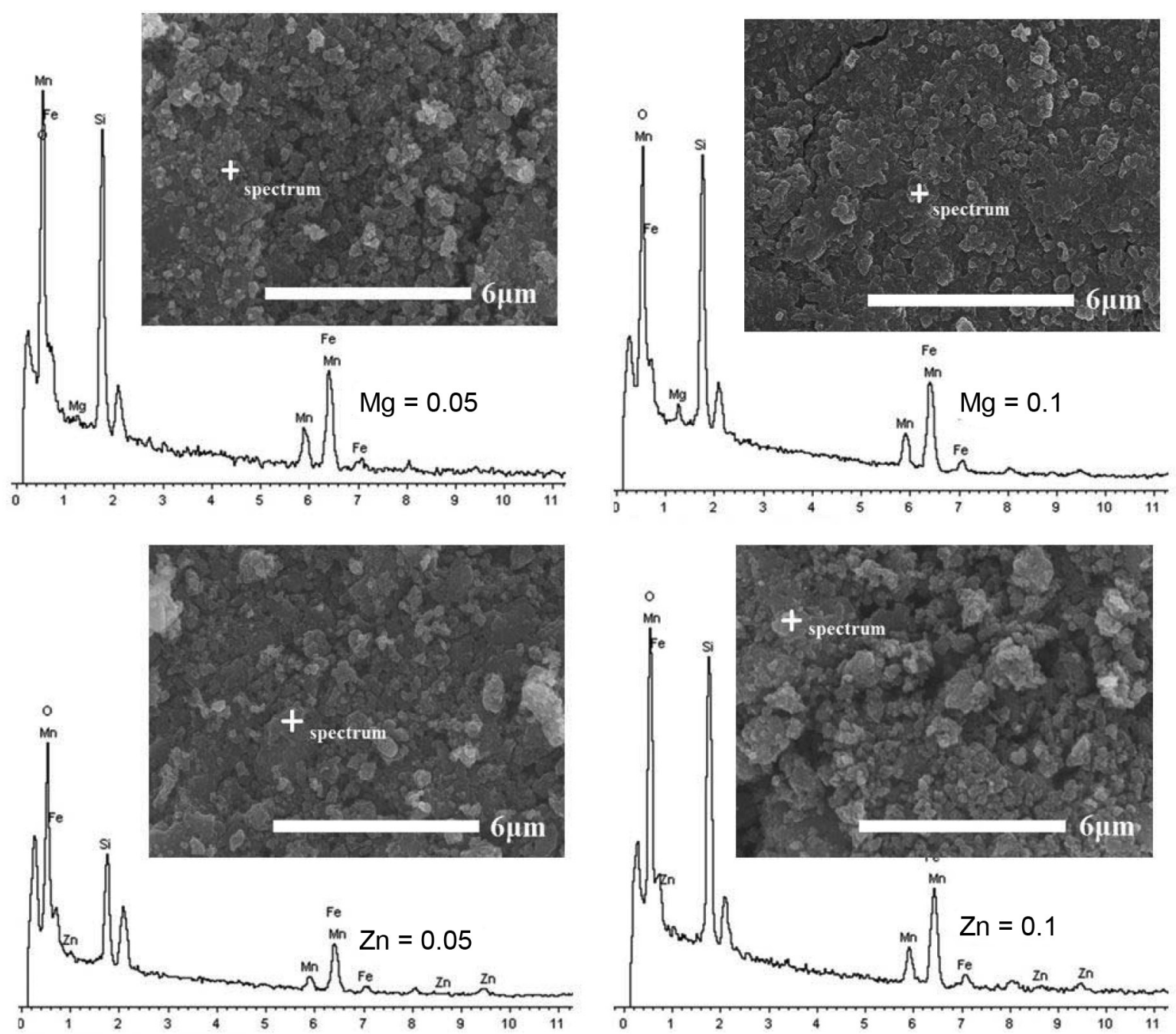

Figure 2. SEM-EDX spot images of original magnification 10,000 $\times$ of $\mathrm{Li}_{2} \mathrm{Fe}_{0.8-\mathrm{x}} \mathrm{Mn}_{0.2} \mathrm{M}_{\mathrm{x}} \mathrm{SiO}_{4}(\mathrm{M}=\mathrm{Mg}$ and $\mathrm{Zn}, \mathrm{x}=0.05$ and 0.1$)$.

Table 1. EDX spot data of $\mathrm{Li}_{2} \mathrm{Fe}_{0.8-\mathrm{x}} \mathrm{Mn}_{0.2} \mathrm{M}_{\mathrm{x}} \mathrm{SiO}_{4}(\mathrm{M}=\mathrm{Mg}$ and $\mathrm{Zn}, \mathrm{x}=0.05$ and 0.1$)$

\begin{tabular}{|c|c|c|c|c|c|}
\hline \multirow{2}{*}{ Sample } & \multicolumn{5}{|c|}{ Atomic / \% } \\
\hline & $\mathrm{Fe} \mathrm{K}$ & Mn K & $\mathrm{M}^{2+} \mathrm{K}$ & Si K & $\mathrm{O} \mathrm{K}$ \\
\hline $\mathrm{Li}_{2} \mathrm{Fe}_{0.75} \mathrm{Mn}_{0.2} \mathrm{Mg}_{0.05} \mathrm{SiO}_{4}$ & 12.22 & 3.39 & 0.88 & 16.69 & 66.82 \\
\hline $\mathrm{Li}_{2} \mathrm{Fe}_{0.7} \mathrm{Mn}_{0.2} \mathrm{Mg}_{0.1} \mathrm{SiO}_{4}$ & 11.74 & 3.25 & 1.77 & 16.22 & 67.02 \\
\hline $\mathrm{Li}_{2} \mathrm{Fe}_{0.75} \mathrm{Mn}_{0.2} \mathrm{Zn}_{0.05} \mathrm{SiO}_{4}$ & 12.62 & 3.32 & 0.83 & 16.71 & 66.52 \\
\hline $\mathrm{Li}_{2} \mathrm{Fe}_{0.7} \mathrm{Mn}_{0.2} \mathrm{Zn}_{0.1} \mathrm{SiO}_{4}$ & 12.64 & 3.56 & 1.95 & 17.23 & 64.62 \\
\hline
\end{tabular}

example, $\mathrm{Li}_{2} \mathrm{Fe}_{0.8-\mathrm{x}} \mathrm{Mn}_{0.2} \mathrm{Mg}_{\mathrm{x}} \mathrm{SiO}_{4}$ samples show the discharge capacities of 74.9 and $63.2 \mathrm{mAh} \mathrm{g}^{-1}$ after 50 cycles, when $\mathrm{x}$ is 0.05 and 0.1 , and the corresponding capacity retentions are 63.5 and $58.2 \%$, as compared to their initial discharge capacities, respectively. Similarly, capacity retention is $\mathbf{5 3 . 6}$ and $69.5 \%$ for $\mathrm{Li}_{2} \mathrm{Fe}_{0.8-\mathrm{x}} \mathrm{Mn}_{0.2} \mathrm{Zn}_{\mathrm{x}} \mathrm{SiO}_{4}$ samples, in spite of their lower discharge capacities of 51.9 and $55.3 \mathrm{mAh} \mathrm{g}^{-1}$ at $50^{\text {th }}$ cycle. We think that the inactive $\mathrm{M}^{2+}$ could have the buttressing effect on crystal lattice when $\mathrm{Li}$-ions are extracted from host cathodes. ${ }^{30}$ Therefore, the co-doped materials have more resistance to amorphisation than $\mathrm{Li}_{2} \mathrm{Fe}_{0.8} \mathrm{Mn}_{0.2} \mathrm{SiO}_{4}$. However, along this inference, $\mathrm{Li}_{2} \mathrm{Fe}_{0.8-\mathrm{x}} \mathrm{Mn}_{0.2} \mathrm{Mg}_{\mathrm{x}} \mathrm{SiO}_{4}$ samples show the opposite result. The capacity retention of $x=0.1$ is only $58.2 \%$, less than $63.5 \%$ of $x=0.05$. A similar phenomenon was explained by Huang $\mathrm{et} \mathrm{al.}{ }^{31}$ that the existence of too many doping ions in the crystal lattice may induce large changes to the structure and cause the phase instability. (v) Among all samples, $\mathrm{Li}_{2} \mathrm{Fe}_{0.75} \mathrm{Mn}_{0.2} \mathrm{Mg}_{0.05} \mathrm{SiO}_{4}$ shows the most excellent performance in charge-discharge capacity and cycling property. 

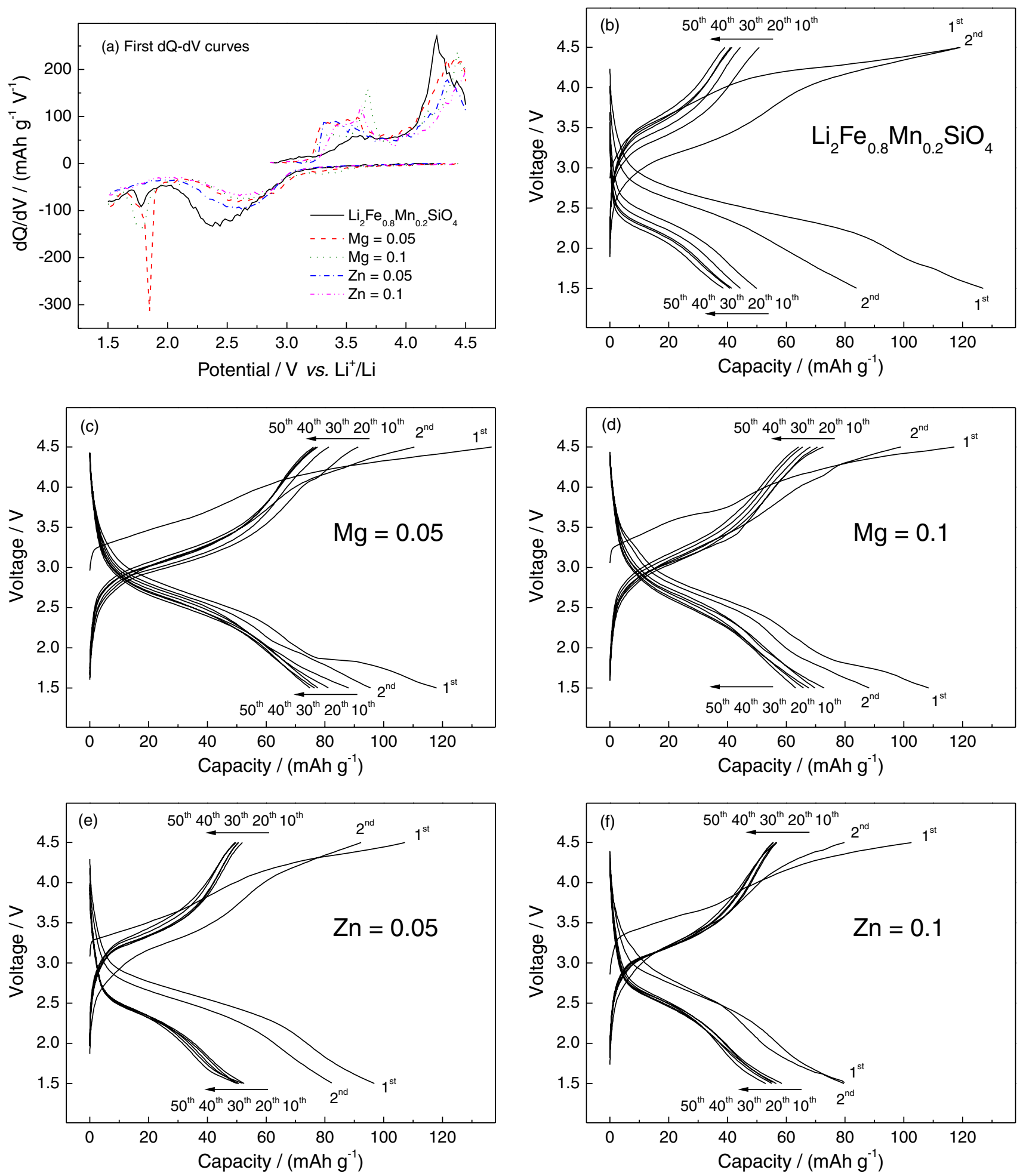

Figure 3. Typical initial dQ/dV and charge-discharge curves of $\mathrm{Li}_{2} \mathrm{Fe}_{0.8-\mathrm{x}} \mathrm{Mn}_{0.2} \mathrm{M}_{\mathrm{x}} \mathrm{SiO}_{4} / \mathrm{Li}$ cells $(\mathrm{M}=\mathrm{Mg}$ and $\mathrm{Zn}, \mathrm{x}=0,0.05$ and 0.1$)$.

Due to low $\mathrm{Li}^{+}$diffusivity and poor electronic conductivity of silicate cathodes, $\mathrm{Li}_{2} \mathrm{MSiO}_{4}$ materials usually have a major drawback to their capacity performances, especially at high rates. As shown in Figure 4, all $\mathrm{Li}_{2} \mathrm{Fe}_{0.8-\mathrm{x}} \mathrm{Mn}_{0.2} \mathrm{M}_{\mathrm{x}} \mathrm{SiO}_{4} / \mathrm{Li}$ cells present poor rate performances in the current range from 0.25 to $2 \mathrm{C}$. Among these samples, only $\mathrm{Li}_{2} \mathrm{Fe}_{0.75} \mathrm{Mn}_{0.2} \mathrm{Mg}_{0.05} \mathrm{SiO}_{4} / \mathrm{Li}$ cell has an improved rate performance, whose discharge capacity is 78.1, 69.7, 58.2, 49.8, 40.7 and $35.6 \mathrm{mAh} \mathrm{g}^{-1}$ at the current rates of $0.25,0.375,0.5,0.75,1.0,2.0 \mathrm{C}$, respectively. 


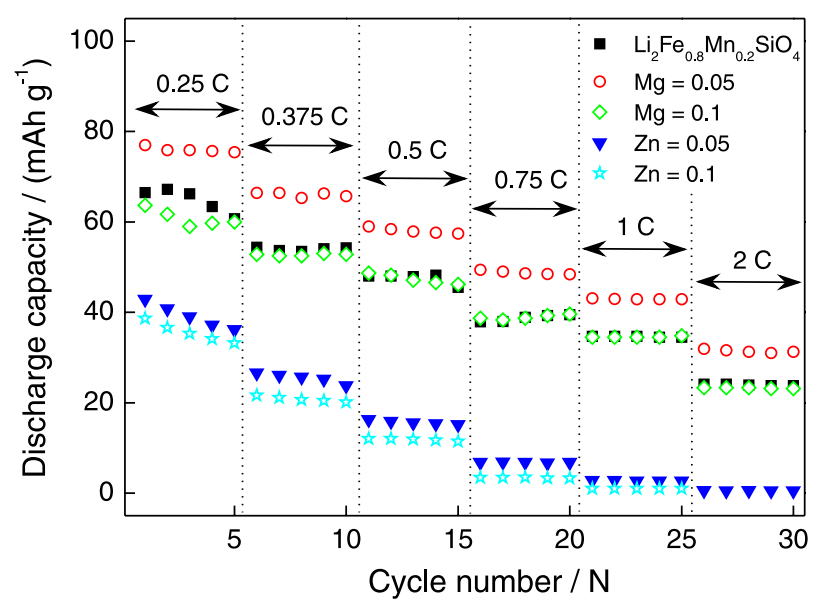

Figure 4. Rate capabilities of $\mathrm{Li}_{2} \mathrm{Fe}_{0.8-x} \mathrm{Mn}_{0.2} \mathrm{M}_{x} \mathrm{SiO}_{4} / \mathrm{Li}$ cells $(\mathrm{M}=\mathrm{Mg}$ and $\mathrm{Zn}, \mathrm{x}=0,0.05$ and 0.1 ).

However, when $\mathrm{Mg}^{2+}$ content increases to 0.1 , the sample has a similar performance to that of $\mathrm{Li}_{2} \mathrm{Fe}_{0.8} \mathrm{Mn}_{0.2} \mathrm{SiO}_{4}$. By contrast, both the $\mathrm{Mn} / \mathrm{Zn}$ co-doped samples presented worse rate performances, especially $\mathrm{Li}_{2} \mathrm{Fe}_{0.7} \mathrm{Mn}_{0.2} \mathrm{Zn}_{0.1} \mathrm{SiO}_{4}$ even does not work at $2.0 \mathrm{C}$.

Figure 5 depicts the $C V$ curves of $\mathrm{Li}_{2} \mathrm{Fe}_{0.8-x} \mathrm{Mn}_{0.2} \mathrm{M}_{\mathrm{x}} \mathrm{SiO}_{4} / \mathrm{Li}$ cells, conducted at a scan rate of $1.0 \mathrm{mV} \mathrm{s}^{-1}$ to elucidate the redox chemistry in a better way. All the $\mathrm{CV}$ profiles are similar. A strong reduction peak with good repeatability appears at about $2.4 \mathrm{~V}$ in the cathodic scan, while the anodic scan exhibits two broad oxidation peaks, in which the lower voltage oxidation peak (LOP) at about $3.4 \mathrm{~V}$ can be attributed to the dominating $\mathrm{Fe}^{2+} / \mathrm{Fe}^{3+}$ redox process on cycling, ${ }^{6,32}$ it is located at a slightly higher potential (3.6-3.8 V) in the first cycle. In view of Wang et al. ${ }^{33}$ the $\mathrm{CV}$ curves of $\mathrm{Li}_{2} \mathrm{MnSiO}_{4} / \mathrm{Li}$ cells showed two oxidation peaks located at 4.4 and $4.8 \mathrm{~V}$ corresponding to the $\mathrm{Mn}^{2+} / \mathrm{Mn}^{3+}$ and $\mathrm{Mn}^{3+} / \mathrm{Mn}^{4+}$ redox couples during the initial charge, respectively. Then they moved obviously to the lower voltages in the subsequent cycles. Therefore, the higher voltage oxidation peak $(\mathrm{HOP},>4.2 \mathrm{~V}$ ) in our experiment can be mainly associated with the $\mathrm{Mn}^{2+} / \mathrm{Mn}^{3+}$ redox couple except for the initial charge. Possibly, there may be a few $\mathrm{Fe}^{3+} / \mathrm{Fe}^{4+}$ reactions occurred at local crystal structure.

In the case of $\mathrm{Li}_{2} \mathrm{Fe}_{0.8} \mathrm{Mn}_{0.2} \mathrm{SiO}_{4}$, the oxidation peak $(>4.2 \mathrm{~V})$ of the second scan is significantly lower than that of the first cycle, as shown in Figure 5a. This observation just matches up with the conclusion suggested by Chen et al. ${ }^{15}$ that the redox processes of $\mathrm{Mn}$ species only can be involved in the first few charge-discharge cycles. As for the $\mathrm{Mn} / \mathrm{Mg}$ co-doped samples (Figures 5b and 5c), we can notice three changes: (i) during the first lithium de-intercalation process, the $\mathrm{Mn} / \mathrm{Mg}$ co-doped samples have lower first LOP than the other samples. When $\mathrm{x}=0.05$, LOP presents a significant peak at $3.3 \mathrm{~V}$ accompanied with a weak transition peak at $3.7 \mathrm{~V}$. However, when $\mathrm{x}=0.1$, the LOP always stays at about $3.35 \mathrm{~V}$. By contrast, the corresponding LOP locate at $3.75 \mathrm{~V}$ for $\mathrm{Li}_{2} \mathrm{Fe}_{0.8} \mathrm{Mn}_{0.2} \mathrm{SiO}_{4}, 3.8$ and $3.65 \mathrm{~V}$ for the $\mathrm{Mn} /$ $\mathrm{Zn}$ co-doped samples, respectively. This fact indicates that, the Mg-substituted system has a smaller inner polarization, which usually means an easier lithium de-intercalation from host cathode. Here, the lower HOP suggests that $\mathrm{Mg}^{2+}$ doping could reduce the energy barrier for lithium migration; (ii) the intensity of $\mathrm{HOP}(>4.2 \mathrm{~V})$ only showed a slight decline with increasing cycles, suggesting that the incorporation of $\mathrm{Mg}^{2+}$ may be better to improve the oxidation from $\mathrm{M}^{3+}$ to $\mathrm{M}^{4+}$; (iii) $\mathrm{CV}$ profiles of $\mathrm{Li}_{2} \mathrm{Fe}_{0.8-\mathrm{x}} \mathrm{Mn}_{0.2} \mathrm{Mg}_{\mathrm{x}} \mathrm{SiO}_{4}$ samples have a better reproducibility in the test range of $1^{\text {st }}-5^{\text {th }}$ cycle, implying the better electrode stability. By contrast, the $\mathrm{Mn} / \mathrm{Zn}$ codoped samples have extremely similar $\mathrm{CV}$ characteristics to $\mathrm{Li}_{2} \mathrm{Fe}_{0.8} \mathrm{Mn}_{0.2} \mathrm{SiO}_{4}$ sample except for some slight differences in redox peak position and response current intensity. Notice that the HOP intensity $(>4.2 \mathrm{~V})$ is smaller and decreases rapidly; this suggests that the incorporation of $\mathrm{Zn}^{2+}$ could impair the oxidation from $\mathrm{M}^{3+}$ to $\mathrm{M}^{4+}$.

Then, we calculated the intervals between the oxidation peak and the reduction peak during the first five $\mathrm{CV}$ cycles, which have been compared in Figure 5f. Because the oxidation peaks of HOP $(>4.2 \mathrm{~V})$ is incomplete, limited by the voltage upper limit of $4.5 \mathrm{~V}$, all the data come from the oxidation peak around $3.4 \mathrm{~V}$ and the reduction peak around $2.4 \mathrm{~V}$. Moreover, the mean peak separation were used in the $2^{\text {nd }}-5^{\text {th }} \mathrm{CV}$ cycles, the single difference was used at the first $\mathrm{CV}$ when considering structural rearrangement. This indicates that the introduction of $\mathrm{Mg}^{2+}$ can help to lessen the inner polarization during the initial structural rearrangement process. In the subsequent $\mathrm{CV}\left(2^{\text {nd }}-5^{\text {th }}\right)$, the single doped sample $\left(\mathrm{Li}_{2} \mathrm{Fe}_{0.8} \mathrm{Mn}_{0.2} \mathrm{SiO}_{4}\right)$ presents the smallest value $(0.7748 \mathrm{~V})$, while the peak intervals after $\mathrm{M}^{2+}$ co-doping have different growth. Especially, in either case, the $\mathrm{Mn} / \mathrm{Zn}$ co-doped samples show noticeable increases in polarization. The fact that more $\mathrm{M}^{2+}$ doping leads to the greater polarization suggests that the incorporation of electrochemically inactive $\mathrm{M}^{2+}$ ions could impede the extraction of Li-ions at LOP to some extent. ${ }^{29}$ This result seems to be contradictory with cycling performances, because smaller resistance usually means better cell performance. However, note that $\mathrm{CV}$ data only present the mean peak intervals of $2^{\text {nd }}-5^{\text {th }}$ scan, thus taking them as evidence to explain long-cycling performance seems to be insufficient. In addition, the absence of HOP $(>4.2 \mathrm{~V})$ might also bring certain errors in $\mathrm{CV}$ results.

Figure 6 shows XRD patterns and EIS spectra of the cycled $\mathrm{Li}_{2} \mathrm{Fe}_{0.8 \mathrm{x}} \mathrm{Mn}_{0.2} \mathrm{M}_{\mathrm{x}} \mathrm{SiO}_{4}$ samples. In Figure 6a, all the XRD patterns are similar and appear no sharp peaks. This proved a transformation from crystal structure into 

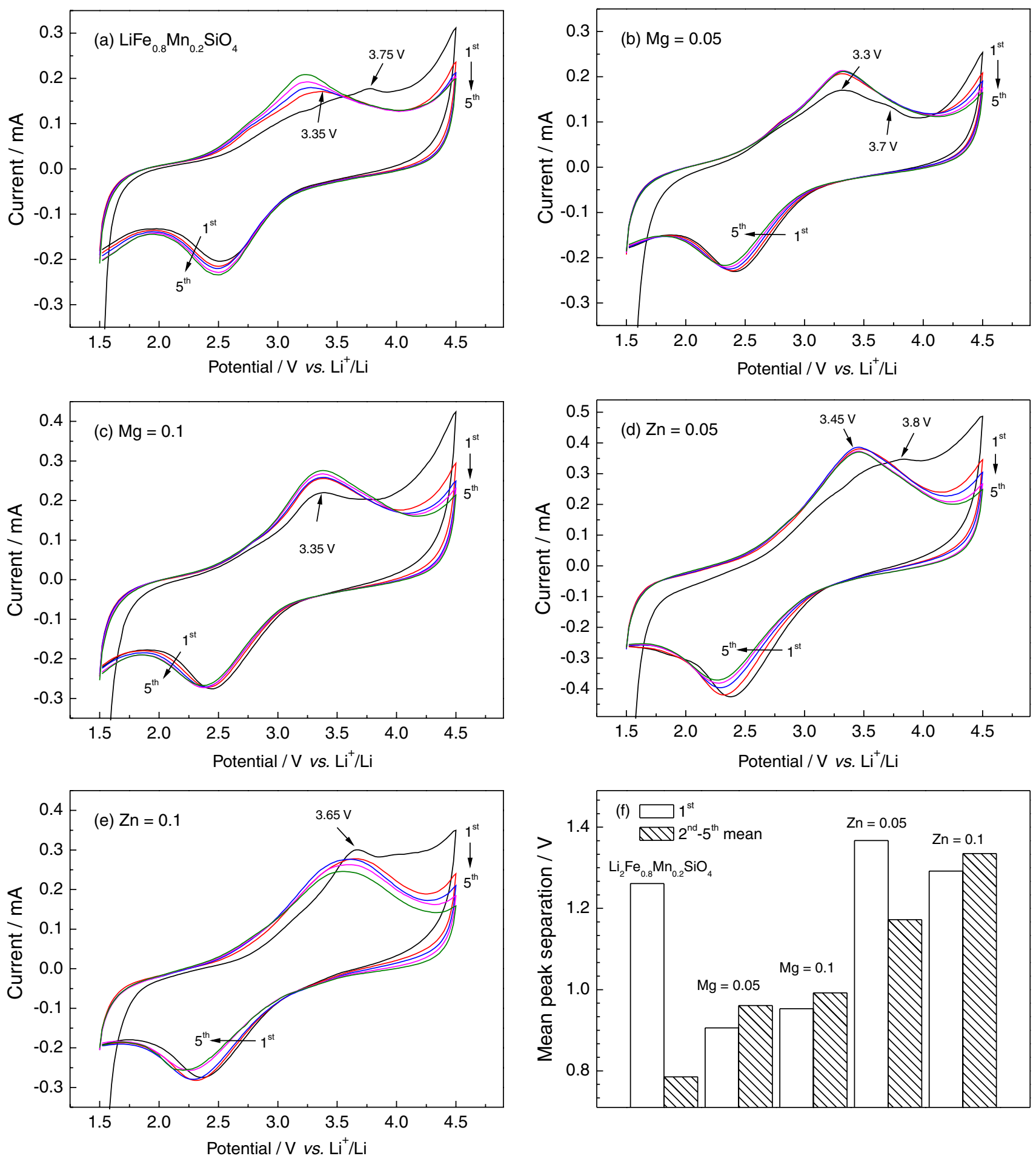

Figure 5. The first five $C V$ profiles (a-e) and mean peak separation; (f) of $\mathrm{Li}_{2} \mathrm{Fe}_{0.8-\mathrm{x}} \mathrm{Mn}_{0.2} \mathrm{M}_{\mathrm{x}} \mathrm{SiO}_{4} / \mathrm{Li}$ cells $(\mathrm{M}=\mathrm{Mg}$ and $\mathrm{Zn}, \mathrm{x}=0,0.05$ and 0.1$)$.

amorphous phase occurred after 50 cycles. Different from prior $\mathrm{CV}$ results presented in the first few cycles, the co-doped samples did not show a long-life advantage in structural stability. The Nyquist plots shown in Figure $6 \mathrm{~b}$ are composed of a semicircle at middle frequency and a slope line at low frequency. The sloped line is related to the $\mathrm{Li}^{+}$diffusion in the electrode material, and the semicircle is connected with the interfacial impedance $\left(\mathrm{R}_{\mathrm{i}}\right)$ including charge-transfer impedance $\left(\mathrm{R}_{\mathrm{ct}}\right)$ and solid electrolyte interphase impedance $\left(\mathrm{R}_{\mathrm{SEI}}\right){ }^{34}$ The spectra can be fitted by the equivalent circuit in our previous work. ${ }^{25}$ The obtained $\mathrm{R}_{\mathrm{i}}$ values were $278 \Omega$ for $\mathrm{Li}_{2} \mathrm{Fe}_{0.8} \mathrm{Mn}_{0.2} \mathrm{SiO}_{4}, 289$ and $404 \Omega$ for the Mg co-doped samples, 626 and $667 \Omega$ for the $\mathrm{Zn}$ co-doped samples, respectively. This result indicates that 

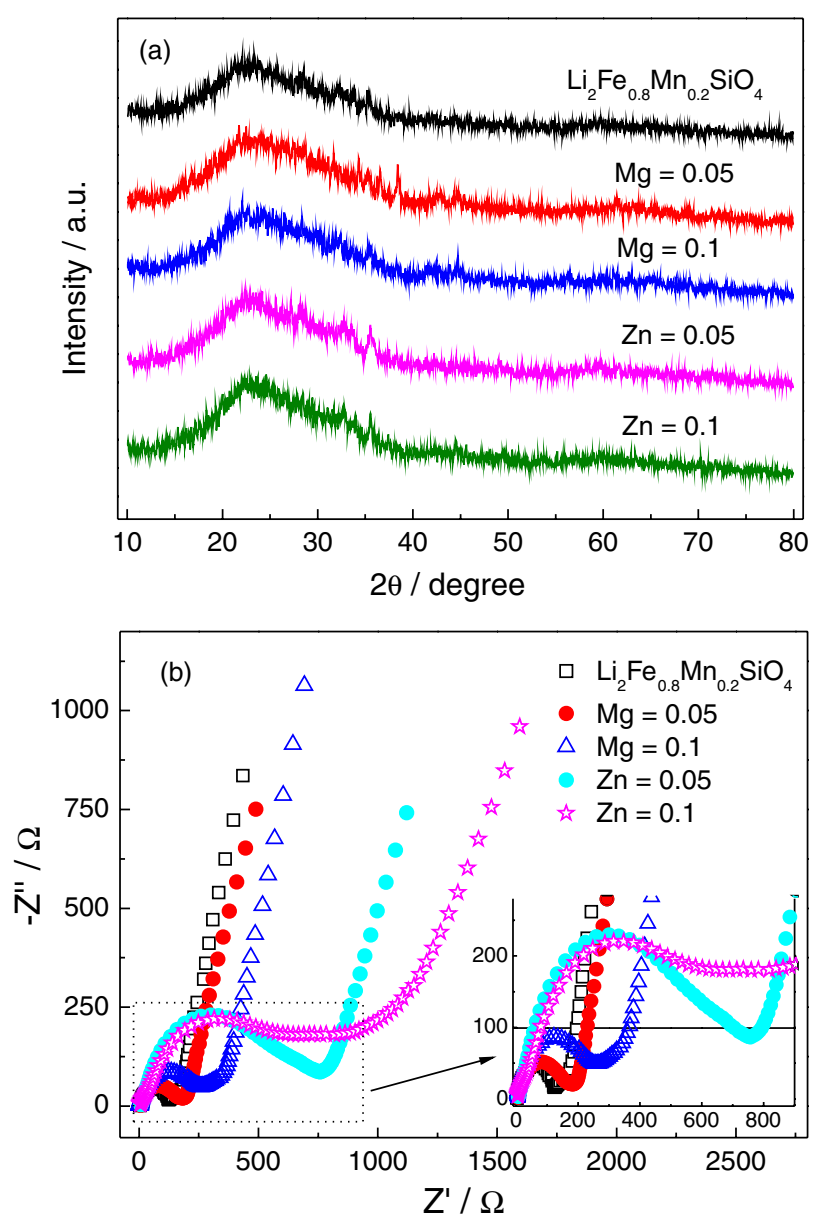

Figure 6. XRD patterns (a) of $\mathrm{Li}_{2} \mathrm{Fe}_{0.8-\mathrm{x}} \mathrm{Mn}_{0.2} \mathrm{M}_{\mathrm{x}} \mathrm{SiO}_{4}$ after 50 cycles; (b) EIS spectra of the cycled cells.

the co-dopping lead to bigger $\mathrm{R}_{\mathrm{i}}$ values, especially for the incorporation of $\mathrm{Zn}^{2+}$. Therefore, the above XRD and EIS results cannot give sufficient reasons for the improved performance of $\mathrm{Li}_{2} \mathrm{Fe}_{0.75} \mathrm{Mn}_{0.2} \mathrm{Mg}_{0.05} \mathrm{SiO}_{4}$. To further reveal this issue, we carried out CITT measurements of $\mathrm{Li}_{2} \mathrm{Fe}_{0.8-x} \mathrm{Mn}_{0.2} \mathrm{M}_{x} \mathrm{SiO}_{4} / \mathrm{Li}$ cells.

The CITT technique was used to determine $\mathrm{D}_{\mathrm{Li}+}$ values. Figure 7 compares the obtained CITT curves with various stair-step shapes. It can be seen that the voltage increases gradually in galvano-charge step and the current decreases gradually in the potentio-charge step. According to the reports, ${ }^{35}$ the following equation can be derived from the spherical diffusion model.

$\mathrm{q}=\frac{\mathrm{Q}_{\mathrm{p}}}{\mathrm{Q}_{\mathrm{g}}}=\frac{\mathrm{r}^{2}}{3 \mathrm{D}_{\mathrm{Li}^{+}} \mathrm{t}_{\mathrm{G}}}\left[\frac{1}{5}-2 \sum_{\mathrm{j}=1}^{\infty} \frac{\mathrm{a}_{\mathrm{j}}^{2}}{\exp }\left(-\frac{\mathrm{a}_{\mathrm{j}}^{2} \mathrm{D}_{\mathrm{L}^{+}} \mathrm{t}_{\mathrm{G}}}{\mathrm{r}^{2}}\right)\right]$

where $\mathrm{q}$ is the ratio of $\mathrm{Q}_{\mathrm{p}}$ and $\mathrm{Q}_{\mathrm{g}}, \mathrm{t}_{\mathrm{G}}$ is the galvano-charge time (s), $\mathrm{r}$ is the mean crystallite size, $\alpha_{\mathrm{j}}$ is constant. Therefore, the equation gives the analytical solution associating $q$ value with the $\mathrm{D}_{\mathrm{Li}+}$. We can get the desired
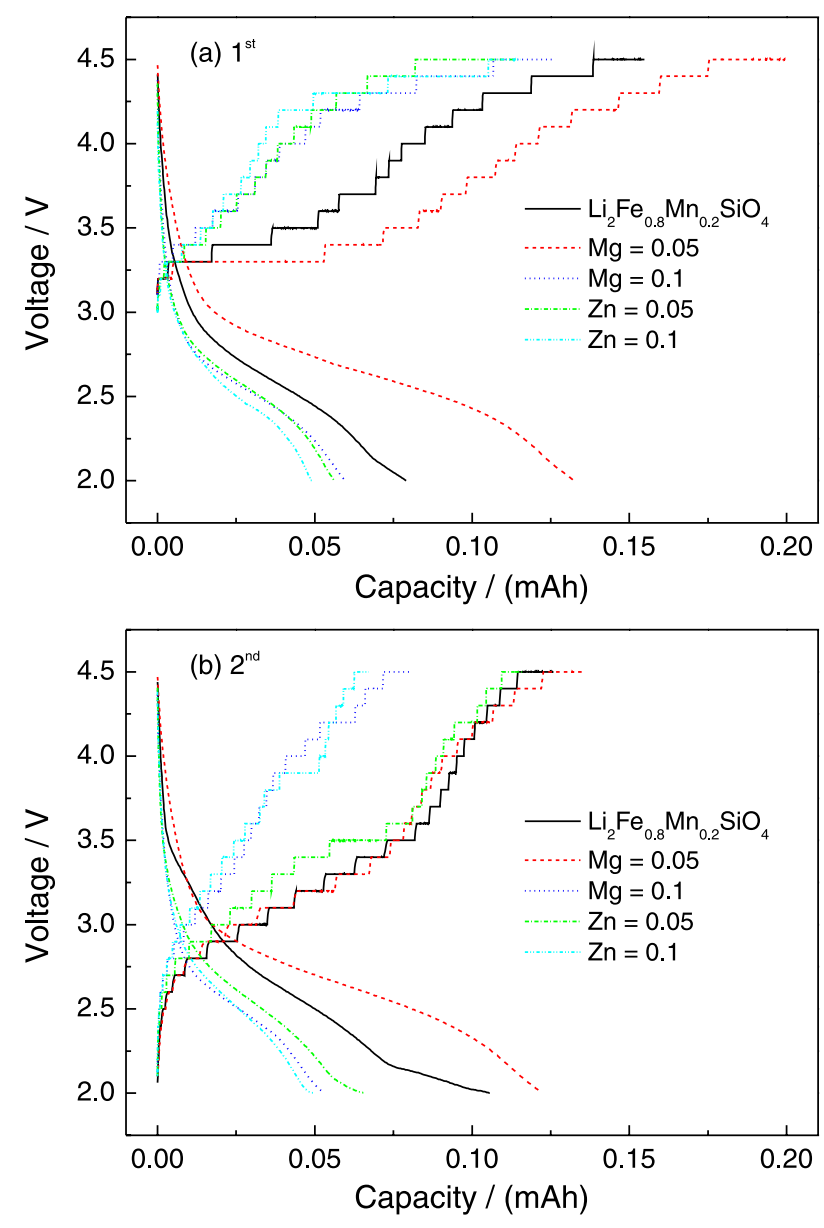

Figure 7. The first two CITT curves of $\mathrm{Li}_{2} \mathrm{Fe}_{0.8-\mathrm{x}} \mathrm{Mn}_{0.2} \mathrm{M}_{\mathrm{x}} \mathrm{SiO} \mathrm{O}_{4} / \mathrm{Li}$ cells $(\mathrm{M}=\mathrm{Mg}$ and $\mathrm{Zn}, \mathrm{x}=0,0.05$ and 0.1$)$.

data from the CITT curves in Figure 7, and then select the equations fitted by linear least-square fits according to for different ranges of q value to calculate $\mathrm{D}_{\mathrm{Li}+}$ values. ${ }^{36}$

The obtained $\mathrm{D}_{\mathrm{Li}+}$ values are compared in Figure 8 . It can be seen that the $\mathrm{D}_{\mathrm{Li}+}$ values varied non-linearly with the charge voltage as a wavy shape, all the $\mathrm{D}_{\mathrm{Li}+}$ values are almost in the same order of magnitude $\left(10^{-16}\right)$. Although the curve shapes are similar, the $\mathrm{D}_{\mathrm{Li}+}$ values of $\mathrm{Li}_{2} \mathrm{Fe}_{0.75} \mathrm{Mn}_{0.2} \mathrm{Mg}_{0.05} \mathrm{SiO}_{4}$ in the first cycle are higher than that of $\mathrm{Li}_{2} \mathrm{Fe}_{0.8} \mathrm{Mn}_{0.2} \mathrm{SiO}_{4}$ sample, especially when the voltage is higher than $4.2 \mathrm{~V}$. This superiority is still retained during the second charging, in spite of the reversed results in the range of 2.8-4.2 V. The higher $\mathrm{D}_{\mathrm{Li}+}$ values mean better $\mathrm{Li}$ diffusivity, so it proves that the incorporation of $\mathrm{Mg}^{2+}$ can promote the extraction/insertion of $\mathrm{Li}^{+}$in the corresponding range. Also, note that the most $\mathrm{D}_{\mathrm{Li}+}$ values at the same voltage in the second charging are higher than that in the first charging. However, for the $\mathrm{Li}_{2} \mathrm{Fe}_{0.75} \mathrm{Mn}_{0.2} \mathrm{Mg}_{0.05} \mathrm{SiO}_{4}$ sample, the obtained $\mathrm{D}_{\mathrm{Li}+}$ data in the first and second cycle are comparable. Recently, Araujo et al. ${ }^{37}$ pointed out that the $\mathrm{D}_{\mathrm{Li}+}$ values of $\mathrm{Li}_{2} \mathrm{FeSiO}_{4}$ at room temperature 
was only about $10^{-20}-10^{-17} \mathrm{~cm}^{2} \mathrm{~s}^{-1}$, less than other with cathode materials $\left(10^{-13}-10^{-7} \mathrm{~cm}^{2} \mathrm{~s}^{-1}\right)$, therefore the kinetics of diffusion performance need to be improved. In our experiment, the $\mathrm{Mg}^{2+}$ co-doping showed some positive effects on $\mathrm{Li}^{+}$mobility, especially above $4.2 \mathrm{~V}$ range, this may be one reason for its improved cell performances. It is need to point out that, because this study only compares the $\mathrm{D}_{\mathrm{Li}+}$ values of the first two charging, so the corresponding data might not reflect the real potential of electrodes for their long cycling.
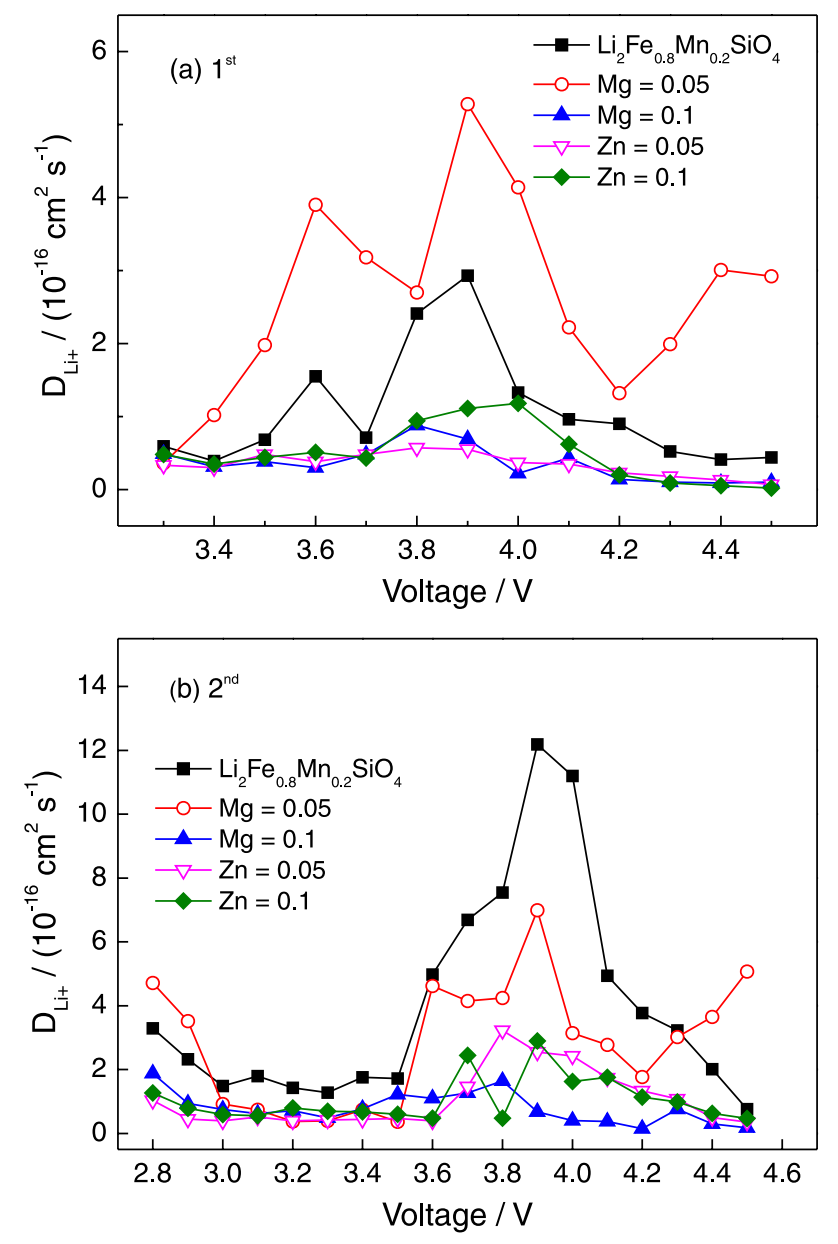

Figure 8. The $\mathrm{D}_{\mathrm{Li}+}$-voltage curves determined from CITT data.

\section{Conclusions}

In this study, $\mathrm{Li}_{2} \mathrm{Fe}_{0.8-\mathrm{x}} \mathrm{Mn}_{0.2} \mathrm{M}_{\mathrm{x}} \mathrm{SiO}_{4}(\mathrm{M}=\mathrm{Mg}$ and $\mathrm{Zn}$, $\mathrm{x}=0,0.05$ and 0.1 ) show very distinct cell performances. Firstly, the incorporation of the electrochemically inactive $\mathrm{M}^{2+}$ ions can serve to strengthen crystal structure and improve the cycling performance significantly. However, note that the capacities show a serious loss with cycling for the $\mathrm{Mn} / \mathrm{Zn}$ co-doped samples. Secondly, the $\mathrm{Mg}^{2+}$ co-doping can bring more benefits, such as the increased capacity $(x=0.05)$ and the improved rate performance.
Thirdly, the XRD and EIS results showed that co-doping leads to the enlarged interfacial resistance and amorphous crystal structure after 50 cycles, but the CV and CITT results suggest that the $\mathrm{Mg}^{2+}$ co-doping should improve $\mathrm{Li}$-ion diffusion behavior at least in the first several cycles, especially above $4.2 \mathrm{~V}$ range. In conclusion, by comparing the $\mathrm{Mg}^{2+}$ and $\mathrm{Zn}^{2+}$ co-doped samples, the $\mathrm{Mg}^{2+}$ with smaller radius seems to be a better choice in this work. The study on the Fe-site co-doping of $\mathrm{Li}_{2} \mathrm{FeSiO}_{4}$ including more elements will be performed in the future.

\section{Acknowledgments}

This work was financially supported by National Natural Science Foundation of China (NSFC) (No. 21003087) and Natural Science Foundation of Shanxi Province (No. 2014011017-4) and National Student Innovation Training Program of China (No. 201510118002) and Students Innovation Training Program of Shanxi Province (No. 2015152).

\section{References}

1. Yang, J. L.; Kang, X. C.; Hu, L.; Gong, X.; He, D. P.; Peng, T.; Mu, S. C.; J. Alloys Compd. 2013, 572, 158.

2. Yang, J. L.; Kang, X. C.; He, D. P.; Peng, T.; Hu, L.; Mu, S. C.; J. Alloys Compd. 2013, 242, 171.

3. Devaraju, M. K.; Tomai, T.; Honma, I.; Electrochim. Acta 2013, $109,75$.

4. Qu, L.; Fang, S. H.; Zhang, Z. X.; Yang, L.; Hirano, S. I.; Mater. Lett. 2013, 108, 1.

5. Peng, G.; Zhang, L. L.; Yang, X. L.; Duan, S.; Liang, G.; Huang, Y. H.; J. Alloys Compd. 2013, 570, 1.

6. Wu, X. Z.; Jiang, X.; Huo, Q. S.; Zhang, Y. X.; Electrochim. Acta 2012, 80, 50.

7. Zhang, S.; Deng, C.; Fu, B. L.; Yang, S. Y.; Ma, L.; J. Electroanal. Chem. 2010, 644, 150.

8. Deng, C.; Zhang, S.; Yang, S. Y.; Fu, B. L.; Ma, L.; J. Power Sources 2011, 196, 386.

9. Zhang, S.; Deng, C.; Fu, B. L.; Yang, S. Y.; Ma, L.; Electrochim. Acta 2010, 55, 8482.

10. Shao, B.; Abe, Y.; Taniguchi, I.; Powder Technol. 2013, 235,1 .

11. Guo, H. J.; Cao, X.; Li, X. Q.; Li, L. M.; Li, X. H.; Wang, Z. X.; Peng, W. J.; Li, Q. H.; Electrochim. Acta 2010, 55, 8036.

12. Deng, C.; Zhang, S.; Yang, S. Y.; J. Alloys Compd. 2009, 487, L18.

13. He, X. G.; Yang, G. L.; Sun, L. Q.; Xie, H. M.; Wang, R. S.; Chem. J. Chinese U. 2010, 31, 2148.

14. Bini, M.; Ferrarin, S.; Capsoni, D.; Spreafico, C.; Tealdi, C.; Mustarelli, P.; J. Solid State Chem. 2013, 200, 70. 
15. Chen, R. C.; Heinzmann, R.; Mangold, S.; Chakravadhanula, V. S. K.; Hahn, H.; Indris, S.; J. Phys. Chem. C 2013, 117, 884.

16. Hu, C.; Yi, H.; Fang, H.; Yang, B.; Yao, Y.; Ma, W.; Dai, Y.; Electrochem. Commun. 2010, 12, 1784.

17. Cui, P.; Liang, Y. S.; Solid State Ionics 2013, 249-250, 129.

18. Tang, X. C.; Li, L. Q.; Huang, B. Y.; He, Y. H.; Solid State Ionics 2006, 177, 687.

19. Sirisopanaporn, C.; Dominko, R.; Masquelier, C.; Armstrong, A. R.; Maliad, G.; Bruce, P. G.; J. Mater. Chem. 2011, 21, 17823.

20. Dimesso, L.; Spanheimer, C.; Jaegermann, W.; J. Alloys Compd. 2014, 582, 69.

21. Dong, Y. Z.; Zhao, Y. M.; Duan, H.; J. Electroanal. Chem. 2011, 660, 14.

22. Dimesso, L.; Spanheimer, C.; Jaegermann, W.; J. Power Sources 2013, 243, 668.

23. Muraliganth, T.; Manthiram, A.; J. Phys. Chem. C 2010, 114, 15530.

24. Gong, Z. L.; Li, Y. X.; Yang, Y.; Electrochem. Solid-State Lett. 2006, 9, A542.

25. Gao, K.; Ionics 2014, 20, 809.

26. Liivat, A.; Solid State Ionics 2012, 228, 19.

27. Eames, C.; Armstrong, A. R.; Bruce, P. G.; Islam, M. S.; Chem. Mater. 2012, 24, 2155.

28. Novikova, S.; Yaroslavtsev, S.; Rusakov, V.; Kulova, T.; Skundin, A.; Yaroslavtsev, A.; Electrochim. Acta 2014, 122, 180 .
29. Reddy, M. V.; Jie, T. W.; Jafta, C. J.; Ozoemena, K. I.; Mathed, M. K.; Nairf, A. S.; Peng, S. S.; Idris, M. S.; Balakrishna, G.; Ezema, F. I.; Chowdari, B. V. R.; Electrochim. Acta 2014, 128, 192.

30. Singh, G.; Gupta, S. L.; Prasad, R.; Auluck, S.; Gupta, R.; Sil, A.; J. Phys. Chem. Solids 2009, 70, 1200.

31. Huang, J. S.; Yang, L.; Liu, K. Y.; Tang, Y. F.; J. Power Sources 2010, 195, 5013.

32. Singh, S.; Mitra, S.; Electrochim. Acta 2014, 123, 378.

33. Wang, F.; Wang, Y. M.; Sun, D. M.; Wang, L.; Yang, J.; Jia, H. P.; Electrochim. Acta 2014, 119, 131.

34. Nytén, A.; Stjerndahl, M.; Rensmo, H.; Siegbahn, H.; Armand, M.; Gustafsson, T.; Edstrom, K.; Thomas, J. O.; J. Mater. Chem. 2006, 16, 3483.

35. Tang, X. C.; Pan, C. Y.; He, L. P.; Li, L. Q.; Chen, Z. Z.; Electrochim. Acta 2004, 49, 3113.

36. Tang, X. C.; Song, X. W.; Shen, P. Z.; Jia, D. Z.; Electrochim. Acta 2005, 50, 5581.

37. Araujo, R. B.; Scheicher, R. H.; de Almeida, J. S.; Ferreira da Silva, A.; Ahuja, R.; Solid State Commun. 2013, 173, 9.

Submitted: January 7, 2016

Published online: March 23, 2016 